OPEN ACCESS

Edited by:

Adolfo Andrade-Cetto,

National Autonomous University of

Mexico, Mexico

Reviewed by:

Subhalakshmi Ghosh,

Jadavpur University, India

Ouyang Chen,

Second Military Medical University,

China

*Correspondence:

Saoirse E. O'Sullivan

mbzso@nottingham.ac.uk

Specialty section:

This article was submitted to

Ethnopharmacology,

a section of the journal

Frontiers in Pharmacology

Received: 29 November 2016

Accepted: 08 February 2017

Published: 24 February 2017

Citation:

Sultan SR, Millar SA, England TJ and O'Sullivan SE (2017) A Systematic

Review and Meta-Analysis of the

Haemodynamic Effects of

Cannabidiol. Front. Pharmacol. 8:81.

doi: 10.3389/fphar.2017.00081

\section{A Systematic Review and Meta-Analysis of the Haemodynamic Effects of Cannabidiol}

\author{
Salahaden R. Sultan, Sophie A. Millar, Timothy J. England and Saoirse E. O'Sullivan * \\ Vascular Medicine, Division of Medical Sciences and Graduate Entry Medicine, Royal Derby Hospital Centre, School of \\ Medicine, University of Nottingham, Derby, UK
}

Despite cannabidiol (CBD) having numerous cardiovascular effects in vitro, its haemodynamic effects in vivo are unclear. Nonetheless, the clinical use of CBD (Epidiolex) is becoming more widespread. The aim of this systematic review was to establish whether CBD is associated with changes in haemodynamics in vivo. Twenty-five studies that assessed the haemodynamic effects of CBD (from PubMed, Medline and EMBASE) were systematically reviewed and meta-analyzed. Data on blood pressure (BP), heart rate $(\mathrm{HR})$, and blood flow $(\mathrm{BF})$ were extracted and analyzed using random effects models. Twenty-two publications assessed BP and HR among 6 species (BP $n=344$ and HR $n=395)$, and 5 publications assessed BF in 3 species $(n=56)$ after acute dosing of CBD. Chronic dosing was assessed in 4 publications in 3 species (total subjects BP, $n=6$; HR, $n=27$; BF, $n=3$ ). Acute CBD dosing had no effect on BP or HR under control conditions. Similarly, chronic dosing with $\mathrm{CBD}$ had no effect on HR. In models of stress, acute CBD administration significantly reduced the increase in BP and HR induced by stress (BP, mean difference (MD) $-3.54,95 \% \mathrm{Cl}-5.19,-1.9, p<0.0001$; $\mathrm{HR}, \mathrm{MD}-16.23,95 \% \mathrm{Cl}-26.44,-6.02, p=0.002)$. In mouse models of stroke, CBD significantly increased cerebral blood flow (CBF, standardized mean difference (SMD) 1.62, 95\% $\mathrm{Cl} 0.41,2.83, p=0.009$ ). Heterogeneity among the studies was present, there was no publication bias except in HR of control and stressful conditions after acute CBD dosing, and median study quality was 5 out of 9 (ranging from 1 to 8). From the limited data available, we conclude that acute and chronic administration of CBD had no effect on BP or HR under control conditions, but reduces BP and HR in stressful conditions, and increases cerebral blood flow (CBF) in mouse models of stroke. Further studies are required to fully understand the potential haemodynamic effects of CBD in humans under normal and pathological conditions.

Keywords: cannabidiol, Epidiolex, CBD, cardiovascular system, haemodynamic, blood pressure, heart rate, blood flow

\section{INTRODUCTION}

Cannabidiol (CBD) is the second most abundant phytocannabinoid, after $\Delta^{9}$ tetrahydrocannabinol (THC) (Pertwee, 2006; Tambaro and Bortolato, 2012) and was first isolated from the cannabis extract in 1940 (Adams et al., 1940). The pharmacological actions of $\mathrm{CBD}$ are complex; $\mathrm{CBD}$ has a low affinity to the cannabinoid receptor $1\left(\mathrm{CB}_{1}\right)$ and cannabinoid 
receptor $2\left(\mathrm{CB}_{2}\right)$ (Thomas et al., 2007; Pertwee, 2008), and targets a wide range of other receptors including 5-hydroxytryptamine $\left(5-\mathrm{HT}_{1 \mathrm{a}}\right)$, transient receptor potential vanilloid receptor 1 (TRPV1), peroxisome proliferator-activated receptors (PPARs) and G protein-coupled receptor 55 (GPR55) (Pertwee, 2008; Stanley et al., 2013a). It is suggested that CBD may have therapeutic effects in a variety of disorders including diabetes, gastrointestinal disturbances, cancer, oxidative stress, inflammation and in cardiovascular disease (Russo and Guy, 2006; Capasso et al., 2008; Zuardi, 2008; Iuvone et al., 2009; Booz, 2011). CBD may also have desirable effects in multiple neurological and psychological disorders, including dystonia, schizophrenia, epilepsy and Parkinson's disease (Consroe et al., 1986; Leweke et al., 2012; Chagas et al., 2014; Devinsky et al., 2016). In a recent open-label trial investigating the effects of CBD (Epidiolex, 2-50 mg/kg) on 214 young patients with treatment-resistant epilepsy, CBD reduced seizure frequency and demonstrated an acceptable safety profile (Devinsky et al., 2016). Epidiolex was also safe and well tolerated in refractory epilepsy secondary to tuberous sclerosis and for epileptic spasms, highlighting its potential as a new treatment for refractory epilepsy (Abati et al., 2015; Geffrey et al., 2015).

Pre-clinical studies on the effects of CBD on the cardiovascular system have shown that CBD causes endotheliumand nitric oxide-dependent vasorelaxation of isolated human mesenteric arteries (Stanley et al., 2015) and PPAR $\gamma$-dependent vasorelaxation of the rat aorta (O'Sullivan et al., 2009). CBD also improves vasorelaxation in the femoral arteries of Zucker diabetic fatty rats via enhanced production of vasodilator COX-1/2-derived products acting at EP4 receptors (Stanley et al., 2013b; Wheal et al., 2014). CBD also decreases myocardial infract size in a rat model of ischaemia/reperfusion injury (Durst et al., 2007), attenuates myocardial dysfunction and inflammation in an animal model of diabetes (Rajesh et al., 2007), and attenuates inflammatory and oxidative stress changes induced by high glucose in human coronary artery cells (Rajesh et al., 2010). CBD also reduces cerebral vascular inflammation and associated dilatation induced by lipopolysaccharide in mice (Ruiz-Valdepenas et al., 2011), infarct size in animal models of stroke (England et al., 2015) and reduced blood brain barrier permeability (Hind et al., 2016). These effects on the cerebral vasculature appear to involve $5 \mathrm{HT}_{1 \mathrm{~A}}$ and $\operatorname{PPAR} \gamma$. Together, these pre-clinical studies might suggest that the cardiovascular system is a therapeutic target for CBD (Stanley et al., 2013a). However, despite these many vascular effects of CBD, it is not yet clear whether $\mathrm{CBD}$ administration alters haemodynamics under control or pathological situations.

Given the increasing clinical use of CBD, and the numerous effects of CBD in the cardiovascular system, the aim of the present study was to systematically review and analyse in vivo studies evaluating the effects of $\mathrm{CBD}$ on alterations in haemodynamics.

\section{MATERIALS AND METHODS}

\section{Search Strategy}

All studies potentially investigating the haemodynamic effect of $\mathrm{CBD}$ (including $\mathrm{BP}, \mathrm{HR}$, and $\mathrm{BF}$ ) were searched (until
November 2016) in Medline, EMBASE, and PubMed. Search keywords included: Cannabidiol, Epidiolex, cardiovascular, blood pressure (BP), systolic, diastolic, hypertension, hypotension, heart rate (HR), tachycardia, bradycardia, blood flow $(\mathrm{BF})$, haemodynamic, vasodilatation, vasorelaxation, and vasoconstriction. References from included studies were also hand searched. Initially, the National Institute for Health and Excellent Care platform was used in which two databases (EMBASE and Medline) were used for searching. Then, a separate search was conducted using PubMed. Pre-specified inclusion and exclusion criteria were used to prevent bias; studies had to be in vivo, assess haemodynamics (BP, HR, or $\mathrm{BF}$ ), be original articles, and be a controlled study. The exclusion criteria were: in vitro studies, mixtures of CBD with other cannabis extracts, studies not assessing haemodynamics (BP, HR, or BF), review articles and editorials, or uncontrolled studies.

\section{Data Acquisition}

Data on BP, HR, and BF were extracted from the included papers, and the changes in haemodynamics at $2 \mathrm{~h}$ post-drug after acute CBD dosing were used for analysis. A standardized time point of $2 \mathrm{~h}$ was decided as this was commonly available throughout the articles and CBD has been previously shown to peak at $2 \mathrm{~h}$ in plasma (Nadulski et al., 2005a,b). If there were no measurements taken at this time point ( $2 \mathrm{~h}$ post-drug) the closest time point to $2 \mathrm{~h}$ was used for analysis. In chronic studies, the mean of total measurements or measurements taken at the end of the study were used for analysis depending on data provided. If the exact number of animals used in each drug group were not available, the authors were contacted. If the authors were not able to provide the necessary information, the lowest number of animals within the range given was used for the experimental group CBD, and the highest number was used for the control group. If a crossover design was used in a study, the total number of humans was distributed equally to the drug groups. Grab application (version 1.5) was used to extract values from figures given in published articles if no values were stated within the text. If published articles used multiple groups (e.g., to assess dose-dependent effects) with one control group, then the number of humans or animals per control group was divided into the number of comparison groups. For the dose-response analysis, the total dose of the drug administrated to species up to the time in which the haemodynamics were measured was used.

\section{Quality}

The methodological quality was assessed to identify risk of bias using six-point criteria derived from the Cochrane collaborations tool for assessing risk of bias (Higgins et al., 2011) and Stroke Therapy Academic Industry Recommendations (STAIR) (Stroke Therapy Academic Industry Roundtable, 1999). Each of the following criteria was equal to 1 point: randomisation, allocation concealment, blinding of outcome assessment, blinding of personnel and participant, assessment of more than one outcome, dose-response relationship, therapeutic time window, assessment of outcome $>24 \mathrm{~h}$ and incomplete outcome data. 


\section{Data Analysis}

Studies were divided into two groups (i.e., acute and chronic). Data were grouped before analysis according to model (nonstress and stress), and then sub-grouped by species (human, mice, rats, etc.). For the $\mathrm{CBD}$ dose-response analysis, data were grouped according to endpoint (BP, HR, or BF), and then subgrouped according to dose. Data from each group were analyzed as forest plots using the Cochrane Review Manager software (Version 5.3. Copenhagen: The Nordic Cochrane Centre, The Cochrane Collaboration, 2014), and as funnel plots using Stata (StataCorp. 2009. Stata Statistical Software: Release 11. College Station, TX, USA). Funnel plot asymmetry (publication bias) was tested by Egger's test (Egger et al., 1997). Stata was also used for meta-regression that described the relationship between CBD dose and effect size. PRISM 7 (GraphPad, Software, La Jolla, CA, USA) was used to produce figures of dose-response. Since heterogeneity was expected between study protocols (different species, models, dose and time) random-effect models were used.
The results of continuous data on $\mathrm{BP}$ and $\mathrm{HR}$ are expressed as mean difference (MD), and as standardized mean difference on BF with 95\% confidence intervals (CIs) due to the different scales used in assessing BF. Studies were weighted by sample size and statistical significance was set at $p<0.05$.

\section{RESULTS}

From the initial 1016 search results, 277 relevant publications were identified from three databases (Medline, EMBASE, and PubMed). Of these, 25 articles met the inclusion criteria (see Figure 1). A summary of the data extracted from included studies is shown in Table $\mathbf{1 .}$

\section{Blood Pressure and Heart Rate}

Ten publications assessed the acute effect of CBD administration on $\mathrm{BP}$, and 15 publications assessed the effect of $\mathrm{CBD}$ administration on HR in 5 species, including humans, mice,

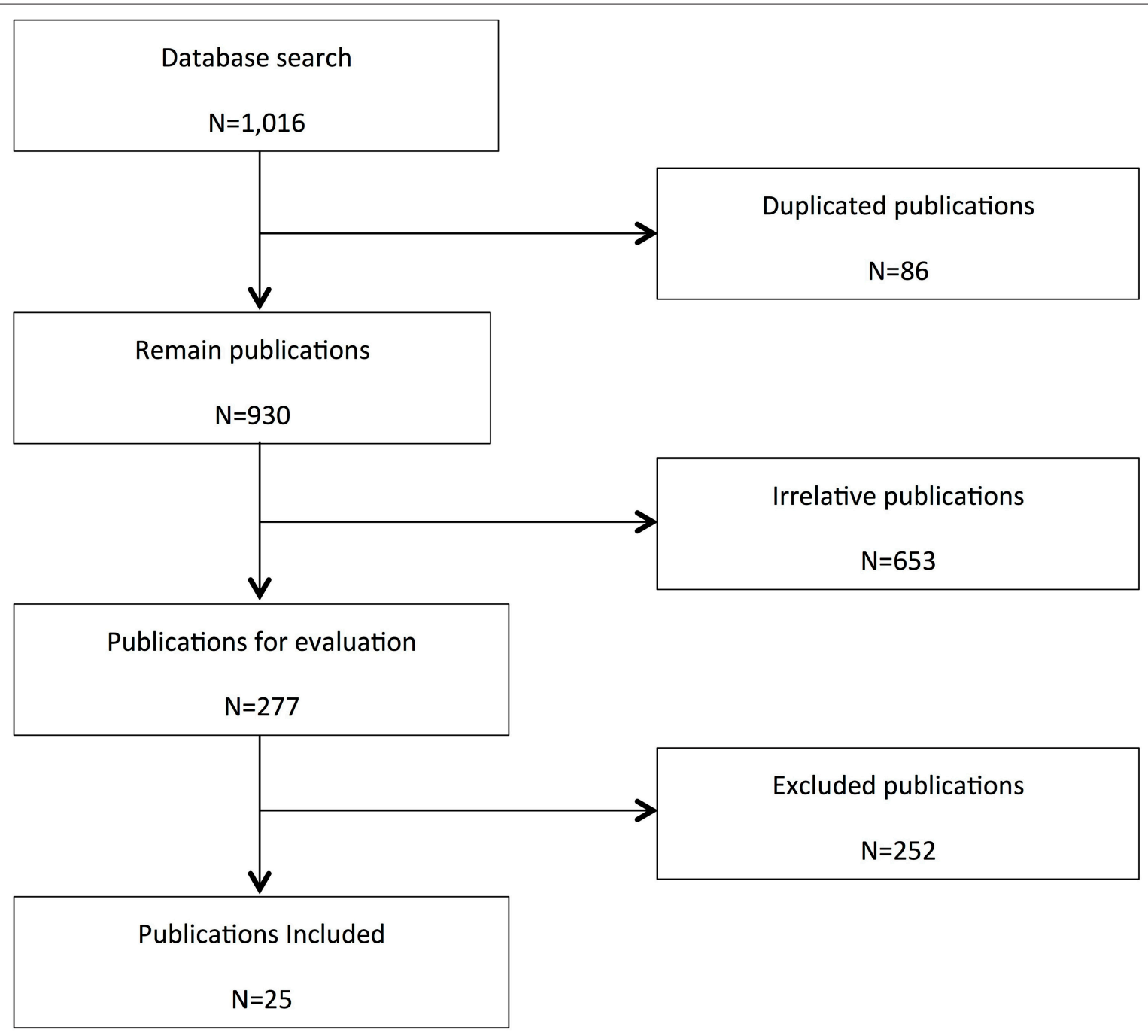

FIGURE 1 | Flow chart for study retrieval and selection. In vitro studies, interaction studies including mixtures of CBD with other cannabis extracts, studies not assessing haemodynamics (BP, HR, or BF), review articles and editorials, or uncontrolled studies were excluded. 
TABLE 1 | Summary of included studies in chronological order.

\begin{tabular}{|c|c|c|c|c|c|c|c|}
\hline Reference & Species & Model & Dose (CBD) & Route & $\begin{array}{l}\text { Time of CBD } \\
\text { administration }\end{array}$ & $\begin{array}{l}\text { Time of haemodynamic } \\
\text { measurements }\end{array}$ & Finding \\
\hline $\begin{array}{l}\text { Borgen and Davis, } \\
1974\end{array}$ & Rabbits & Anaesthetised & $25 \mathrm{mg} / \mathrm{kg}$ & i.v. & Pre-test & $\begin{array}{l}\text { Pre-drug and hourly interval to } \\
7 \mathrm{~h} \text { post-drug }\end{array}$ & $\begin{array}{l}\text { No changes on } \\
\text { HR }\end{array}$ \\
\hline Bright et al., 1975 & Dogs & Anaesthetised & 0.5 or $1 \mathrm{mg} / \mathrm{kg}$ & i.v. & Pre-test & During 30 min post-drug. & $\uparrow M B P$ and $H R$ \\
\hline $\begin{array}{l}\text { Belgrave et al., } \\
1979\end{array}$ & Humans & $\begin{array}{l}\text { Healthy } \\
\text { volunteers }\end{array}$ & $320 \mu \mathrm{g} / \mathrm{kg}$ & Oral & Pre-test & $\begin{array}{l}\text { Pre-drug and at } 1.5,2.5 \text { and } \\
3.5 \text { h post-drug }\end{array}$ & $\begin{array}{l}\text { No changes on } \\
\text { HR }\end{array}$ \\
\hline \multirow[t]{3}{*}{ Gong et al., 1984} & Human & $\begin{array}{l}\text { Healthy } \\
\text { volunteers }\end{array}$ & $\begin{array}{l}100,600 \text { or } \\
1200 \mathrm{mg}\end{array}$ & Oral & Pre-test & Hourly interval to $6 \mathrm{~h}$ post-dru & $\begin{array}{l}\text { No changes on } \\
\text { SBP, DBP or HR }\end{array}$ \\
\hline & & & $1200 \mathrm{mg}$ & & Pre-test & $\begin{array}{l}\text { Hourly interval to } 6 \mathrm{~h} \\
\text { post-drug }\end{array}$ & \\
\hline & & & $1200 \mathrm{mg}$ & & $\begin{array}{l}\text { Single dose per day for } \\
20 \text { days }\end{array}$ & $\begin{array}{l}\text { Hourly interval to } 6 \mathrm{~h} \\
\text { post-drug and on days } 5,12 \\
\text { and } 19\end{array}$ & \\
\hline $\begin{array}{l}\text { Consroe et al., } \\
1991\end{array}$ & Human & $\begin{array}{l}\text { Patients with } \\
\text { Huntington } \\
\text { disease }\end{array}$ & 10 mg/kg & Oral & $\begin{array}{l}\text { Single dose per day for } \\
6 \text { weeks }\end{array}$ & $\begin{array}{l}\text { Pre-drug, during and } \\
\text { post-drug }\end{array}$ & $\begin{array}{l}\text { No changes on } \\
\text { MBP or HR }\end{array}$ \\
\hline Zuardi et al., 1993 & Human & $\begin{array}{l}\text { Healthy } \\
\text { volunteers }\end{array}$ & $300 \mathrm{mg}$ & Oral & Pre-test & $\begin{array}{l}\text { Pre-drug and Post drug at } 80 \\
\text { min (pre-stress), } 85 \text { min } \\
\text { (during stress) and } 100 \text { min } \\
\text { (post-stress) }\end{array}$ & $\begin{array}{l}\text { No changes on } \\
\text { SBP or HR }\end{array}$ \\
\hline \multirow[t]{2}{*}{$\begin{array}{l}\text { Mishima et al., } \\
2005\end{array}$} & Mice & MCAO & $3 \mathrm{mg} / \mathrm{kg}$ & i.p. & $\begin{array}{l}\text { Pre and } 3 \mathrm{~h} \\
\text { post-occlusion }\end{array}$ & $\begin{array}{l}\text { MBP and HR: } 2 \mathrm{~h} \\
\text { post-occlusion }\end{array}$ & $\begin{array}{l}\text { No changes on } \\
\text { MBP or HR }\end{array}$ \\
\hline & & & & & & $\begin{array}{l}\text { CBF: during } 4 \mathrm{~h} \\
\text { post-occlusion }\end{array}$ & $\uparrow \mathrm{CBF}$ \\
\hline $\begin{array}{l}\text { Resstel et al., } \\
2006\end{array}$ & Rats & Stress (fear) & 10 mg/kg & i.p. & Pre-test & $\begin{array}{l}\text { Pre-stress and during } 10 \text { min } \\
\text { post-stress }\end{array}$ & $\begin{array}{l}\downarrow \mathrm{MBP} \text { and } \mathrm{HR} \\
\text { post-stress }\end{array}$ \\
\hline \multirow[t]{2}{*}{$\begin{array}{l}\text { Hayakawa et al., } \\
2007 a\end{array}$} & Mice & MCAO & $3 \mathrm{mg} / \mathrm{kg}$ & i.p. & $\begin{array}{l}\text { Pre, } 3 \text { and } 4 \mathrm{~h} \\
\text { post-occlusion, and } 1 \\
\text { and } 2 \mathrm{~h} \text { post-reperfusion }\end{array}$ & MBP and HR: pre-reperfusio & $\begin{array}{l}\text { No changes on } \\
\text { MBP or HR }\end{array}$ \\
\hline & & & & & & $\begin{array}{l}\text { CBF: during } 4 \mathrm{~h} \text { of occlusion } \\
\text { and post-reperfusion }\end{array}$ & $\uparrow \mathrm{CBF}$ \\
\hline $\begin{array}{l}\text { Hayakawa et al., } \\
2007 b\end{array}$ & Mice & MCAO & $3 \mathrm{mg} / \mathrm{kg}$ & i.p. & $\begin{array}{l}\text { Pre-occlusion and } 3 \mathrm{~h} \\
\text { post-occlusion and } \\
\text { Single dose per day for } \\
14 \text { days }\end{array}$ & $\begin{array}{l}\text { During } 4 \mathrm{~h} \text { and on day } 14 \\
\text { post-occlusion }\end{array}$ & $\uparrow \mathrm{CBF}$ \\
\hline Durst et al., 2007 & Rats & $\begin{array}{l}\text { Myocardial } \\
\text { infarction }\end{array}$ & $5 \mathrm{mg} / \mathrm{kg}$ for 7 days & i.p. & $\begin{array}{l}\text { Pre-ischaemia and } \\
\text { post-ischaemia for } 7 \\
\text { days }\end{array}$ & $\begin{array}{l}\text { On day } 1 \text { and } 7 \\
\text { post-ischaemia }\end{array}$ & $\begin{array}{l}\text { No changes on } \\
\text { HR }\end{array}$ \\
\hline \multirow[t]{2}{*}{ Alvarez et al., 2008} & Piglets & $\begin{array}{l}\text { Carotid } \\
\text { occlusion and } \\
\text { hypoxic } \\
\text { ischaemia }\end{array}$ & $0.1 \mathrm{mg} / \mathrm{kg}$ & i.v. & $\begin{array}{l}15 \mathrm{~min} \text { and } 4 \mathrm{~h} \\
\text { post-procedure }\end{array}$ & $\begin{array}{l}\text { MBP and HR: pre-procedure } \\
\text { and at } 3 \text { and } 6 \mathrm{~h} \\
\text { post-procedure }\end{array}$ & $\begin{array}{l}\text { Maintain MBP } \\
\text { and HR after the } \\
\text { fall post- hypoxic } \\
\text { ischaemia }\end{array}$ \\
\hline & & & & & & $\begin{array}{l}\text { CBF: pre-procedure and } \\
\text { during } 6 \mathrm{~h} \text { post-procedure }\end{array}$ & $\uparrow \mathrm{CBF}$ \\
\hline $\begin{array}{l}\text { Hayakawa et al., } \\
2008\end{array}$ & Mice & MCAO & $3 \mathrm{mg} / \mathrm{kg}$ & i.p. & $\begin{array}{l}\text { Pre-occlusion and } 3 \mathrm{~h} \\
\text { post-occlusion }\end{array}$ & During $4 \mathrm{~h}$ post-occlusion & $\begin{array}{l}\text { No changes on } \\
\text { MBP or HR }\end{array}$ \\
\hline $\begin{array}{l}\text { Resstel et al., } \\
2009\end{array}$ & Rats & Stress (restraint) & 1,10 , or 20 mg/kg & i.p. & Pre-stress & $\begin{array}{l}\text { Pre-stress and during } 1 \mathrm{hr} \\
\text { post-stress }\end{array}$ & $\begin{array}{l}\downarrow \mathrm{MBP} \text { and } \mathrm{HR} \\
\text { post-stress }\end{array}$ \\
\hline Alves et al., 2010 & Rats & Conscious & $60 \mathrm{nmol}$ & BNST & Post-ACSF & During 60 min post-drug & $\begin{array}{l}\text { No changes on } \\
\text { MBP or HR }\end{array}$ \\
\hline Walsh et al., 2010 & Rats & $\begin{array}{l}\text { Myocardial } \\
\text { infarction }\end{array}$ & 10 or $50 \mu \mathrm{g} / \mathrm{kg}$ & i.v. & $\begin{array}{l}\text { Pre-ischaemia and } \\
\text { pre-reperfusion }\end{array}$ & $\begin{array}{l}\text { Pre- ischaemia during } 2.30 \mathrm{~h} \\
\text { post-ischaemia, }\end{array}$ & $\downarrow \mathrm{MBP}$ \\
\hline $\begin{array}{l}\text { Granjeiro et al., } \\
2011\end{array}$ & Rats & Stress (restraint) & 15,30 or $60 \mathrm{nmol}$ & intracisternal & Pre-stress & $\begin{array}{l}\text { Pre-stress and during } 1 \mathrm{hr} \\
\text { post-stress }\end{array}$ & $\begin{array}{l}\text { No change in } \\
\text { MBP or HR }\end{array}$ \\
\hline Hallak et al., 2011 & Human & $\begin{array}{l}\text { Healthy } \\
\text { volunteers }\end{array}$ & $600 \mathrm{mg}$ & Oral & Pre-test & $\begin{array}{l}\text { Pre-drug and at } 30 \mathrm{~min} \\
\text { interval for } 2.30 \mathrm{~h} \text { post-drug }\end{array}$ & $\begin{array}{l}\text { No change in } \\
\text { SBP, DBP or HR }\end{array}$ \\
\hline
\end{tabular}


TABLE 1 | Continued

\begin{tabular}{|c|c|c|c|c|c|c|c|}
\hline Reference & Species & Model & Dose (CBD) & Route & $\begin{array}{l}\text { Time of CBD } \\
\text { administration }\end{array}$ & $\begin{array}{l}\text { Time of haemodynamic } \\
\text { measurements }\end{array}$ & Finding \\
\hline $\begin{array}{l}\text { Gomes et al., } \\
2012\end{array}$ & Rats & Stress (fear) & 15,30 or $60 \mathrm{nmol}$ & BNST & Pre-stress & $\begin{array}{l}\text { Pre-stress and during } 10 \mathrm{~min} \\
\text { post-stress }\end{array}$ & $\begin{array}{l}30 \text { and } 60 \mathrm{nmol}: \\
\downarrow \mathrm{MBP} \text { and } \mathrm{HR}\end{array}$ \\
\hline $\begin{array}{l}\text { Martin-Santos } \\
\text { et al., } 2012\end{array}$ & Human & $\begin{array}{l}\text { Healthy } \\
\text { volunteers }\end{array}$ & $600 \mathrm{mg}$ & Oral & Pre-test & $\begin{array}{l}\text { Pre-drug and Hourly interval } \\
\text { for } 3 \mathrm{~h} \text { post-drug }\end{array}$ & $\begin{array}{l}\text { No changes on } \\
\text { BP or HR }\end{array}$ \\
\hline $\begin{array}{l}\text { Gomes et al., } \\
2013\end{array}$ & Rats & Stress (restraint) & 15,30 or $60 \mathrm{nmol}$ & BNST & Pre-stress & $\begin{array}{l}\text { Pre-stress and during } 60 \mathrm{~min} \\
\text { post-stress }\end{array}$ & $\begin{array}{l}\text { Enhanced the } \\
\text { HR increase } \\
\text { post-stress } \\
\text { No changes on } \\
\text { MBP }\end{array}$ \\
\hline Pazos et al., 2013 & Piglets & $\begin{array}{l}\text { Hypoxic } \\
\text { ischaemia }\end{array}$ & $1 \mathrm{mg} / \mathrm{kg}$ & i.v. & Post-HI & $\begin{array}{l}\text { Pre-drug, at } 30 \text { and } 90 \mathrm{~min} \\
\text { post-HI }\end{array}$ & $\begin{array}{l}\text { No changes on } \\
\text { MBP }\end{array}$ \\
\hline $\begin{array}{l}\text { Gonca and Darici, } \\
2015\end{array}$ & Rats & $\begin{array}{l}\text { Myocardial } \\
\text { infarction }\end{array}$ & $50 \mu \mathrm{g} / \mathrm{kg}$ & i.v. & Pre-ischaemia & $\begin{array}{l}\text { Pre-ishaemia At } 1,5 \text { and } 11 \\
\text { min post-ischaemia }\end{array}$ & $\begin{array}{l}\text { No changes on } \\
\text { BP or HR }\end{array}$ \\
\hline Feng et al., 2015 & Rabbits & $\begin{array}{l}\text { Myocardial } \\
\text { infarction }\end{array}$ & $100 \mu \mathrm{g} / \mathrm{kg}$ & i.v. & Pre-reperfusion & $\begin{array}{l}\text { At } 15,30 \text { and } 45 \mathrm{~min} \\
\text { post-drug }\end{array}$ & $\uparrow \mathrm{BF}$ \\
\hline $\begin{array}{l}\text { Garberg et al., } \\
2016\end{array}$ & Piglets & $\begin{array}{l}\text { Hypoxic } \\
\text { ischaemia }\end{array}$ & $1 \mathrm{mg} / \mathrm{kg}$ & i.v. & Post-HI & $\begin{array}{l}\text { Immediately post } \mathrm{HI} \text { and at } \\
30,210 \text { and } 570 \text { min post-HI }\end{array}$ & $\begin{array}{l}\text { No changes on } \\
\text { BP or HR }\end{array}$ \\
\hline
\end{tabular}

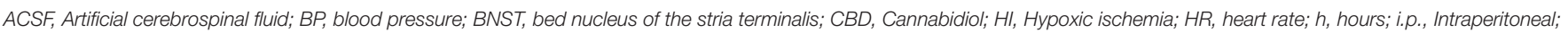
i.v., intravenous; MBP, mean blood pressure; MCAO, middle cerebral artery occlusion; min, minutes; SBP, systolic blood pressure.

dogs, rats, piglets, and rabbits $(n=403)$. Chronic dosing was assessed in 3 publications in 2 species, including humans and rats (BP: one study, $n=6$; HR: 3 studies, $n=27$ ). $\mathrm{CBD}$ had no effect on $\mathrm{BP}$ or $\mathrm{HR}$ after acute dosing (BP, $\mathrm{MD} 3,95 \% \mathrm{CI}-1.81,7.8, p=0.22$; HR, MD $-0.05,95 \%$ CI-2.68, 2.57, $p=0.97$, Figures 2A,B) or chronic dosing (HR MD 0.3, 95\% CI -3.97, 4.57, $p=0.89$, Figure 3). Within species analysis revealed that acute CBD dosing significantly increased HR in rats $(p=0.004$, Figure 2B). Heterogeneity was statistically significant for BP measurements after acute CBD dosing $\left(p=0.0006 ; I^{2}=65 \%\right)$ and $\mathrm{HR}$ measurements after chronic CBD dosing $\left(p=0.05 ; I^{2}=55 \%\right.$; Figures 2, 3).

Six publications assessed the effect of CBD administration on $\mathrm{BP}$ and HR in models of stress in rats and humans $(n=336)$. Overall, CBD administration significantly reduced the increase in BP (BP, MD: $-3.54,95 \%$ CI $-5.19,-1.9, p<0.0001$, Figure 4A) and $\mathrm{HR}$ (HR, MD: $-16.23,95 \% \mathrm{CI}-26.44,-6.02, p=0.002$, Figure 4B) induced by stress. Heterogeneity was statistically significant in both BP $\left(p<0.00001 ; I^{2}=73 \%\right)$ and HR $(p<$ $0.00001 ; I^{2}=92 \%$; Figure 4).

\section{Blood Flow}

Changes in BF after acute CBD dosing were assessed in 5 publications examining the effects of CBD in models of stroke or myocardial infarction in 3 species (mice, piglets and rabbits, $n=56$ ). Overall, CBD had no effects on BF (SMD: 0.58, 95\% CI $-0.1,1.26, p=0.1$ ). However, subgroup analysis showed that $\mathrm{CBD}$ significantly increased cerebral blood flow (CBF) in mouse models of stroke ( $p=0.009$, Figure 5); heterogeneity was not statistically significant $\left(p=0.27 ; I^{2}=21 \%\right)$. As only one study assessed BF after chronic dosing, a meta-analysis was not applicable.

\section{Route of Administration}

We compared differences between local and systemic administration of CBD on haemodynamics. Local (intracisternal or intracerebral) administration of CBD was only used in studies on rats (4 out of 9 studies; 1 under control conditions and 3 under stressful situations). After systemic administration, there was a significant reduction in $\operatorname{HR}$ ( $p<0.0001 ; 2$ studies), but not after local (intracisternal or intracerebral) administration of CBD $(p=0.11 ; 3$ studies $)$.

\section{CBD Dose-Response on Haemodynamics}

The dose-response to $\mathrm{CBD}$ was analyzed to establish if there is a relationship between CBD dose and effect size. Doses ranging from 0.003 to $22800 \mathrm{mg}$ were used in different species of different models. Overall, there was no relationship between drug dose and the size of the effect on haemodynamics (BP $p=0.81, \operatorname{HR} p=$ $0.97, \mathrm{BF} p=0.97$; Figure 6).

\section{Quality}

Among the 25 included publications, 9 publications used randomisation and allocation concealment in their design, 6 reported blinding assessment of outcome and blinding of outcome measurements, 20 publications assessed more than one outcome, 12 conducted dose-response relationships, 19 assessed a time window for intervention, 4 measured outcomes $>24 \mathrm{~h}$ post-drug and 2 publications provided incomplete data due to subject withdrawal There was no significant relationship between quality score and any outcome except in BF (Spearman's rho coefficient of BP, $-0.1, p=0.54, \mathrm{HR}, 0.06, p=0.66$ and $\mathrm{BF}, 0.87$, $p=0.01)$.

\section{Publication Bias}

Egger's test showed no bias present except in studies assessing for changes in HR in either control or stressful conditions after acute 


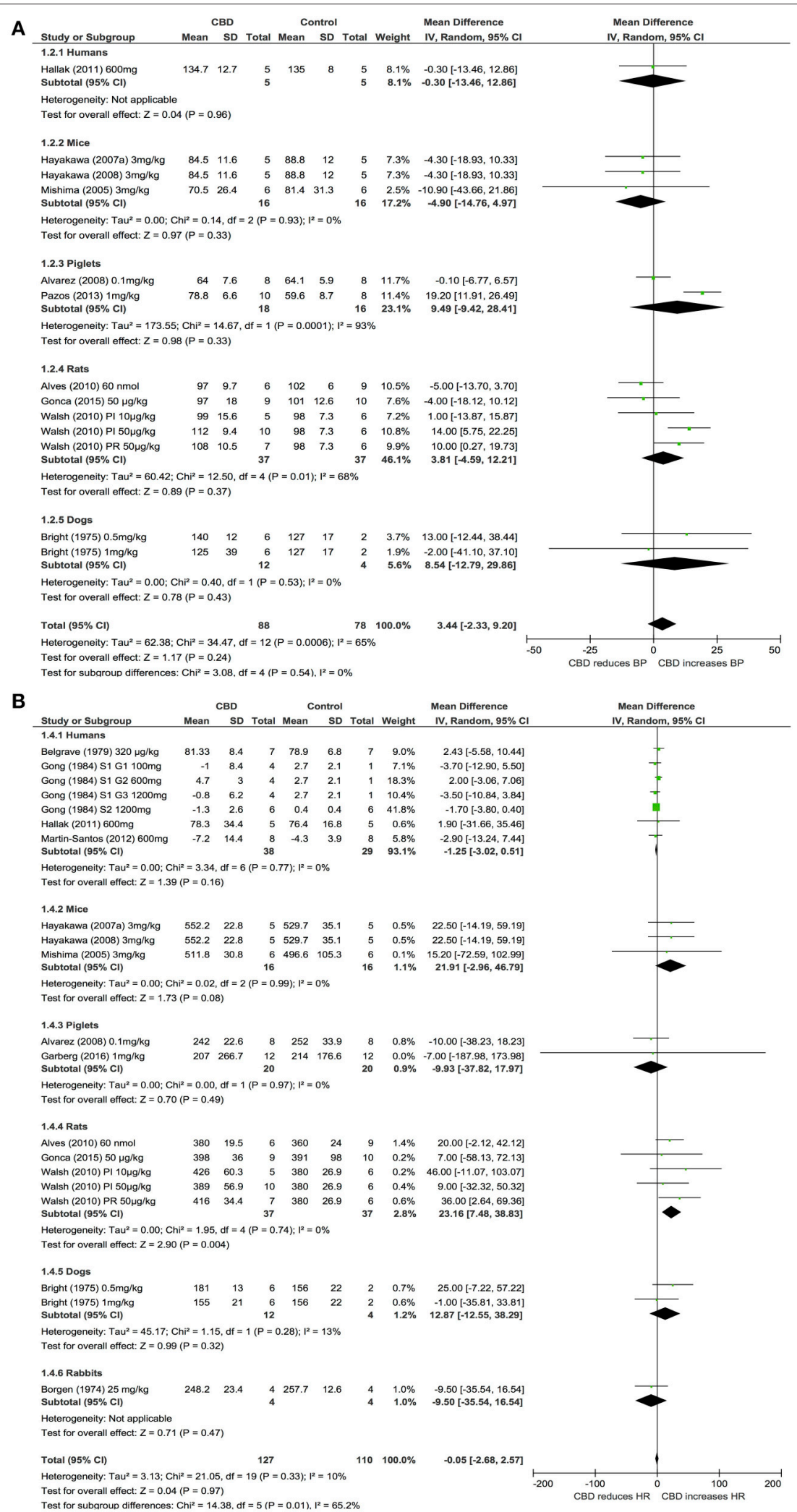

FIGURE 2 | Changes in BP (A) and HR (B) induced by acute CBD dosing. 


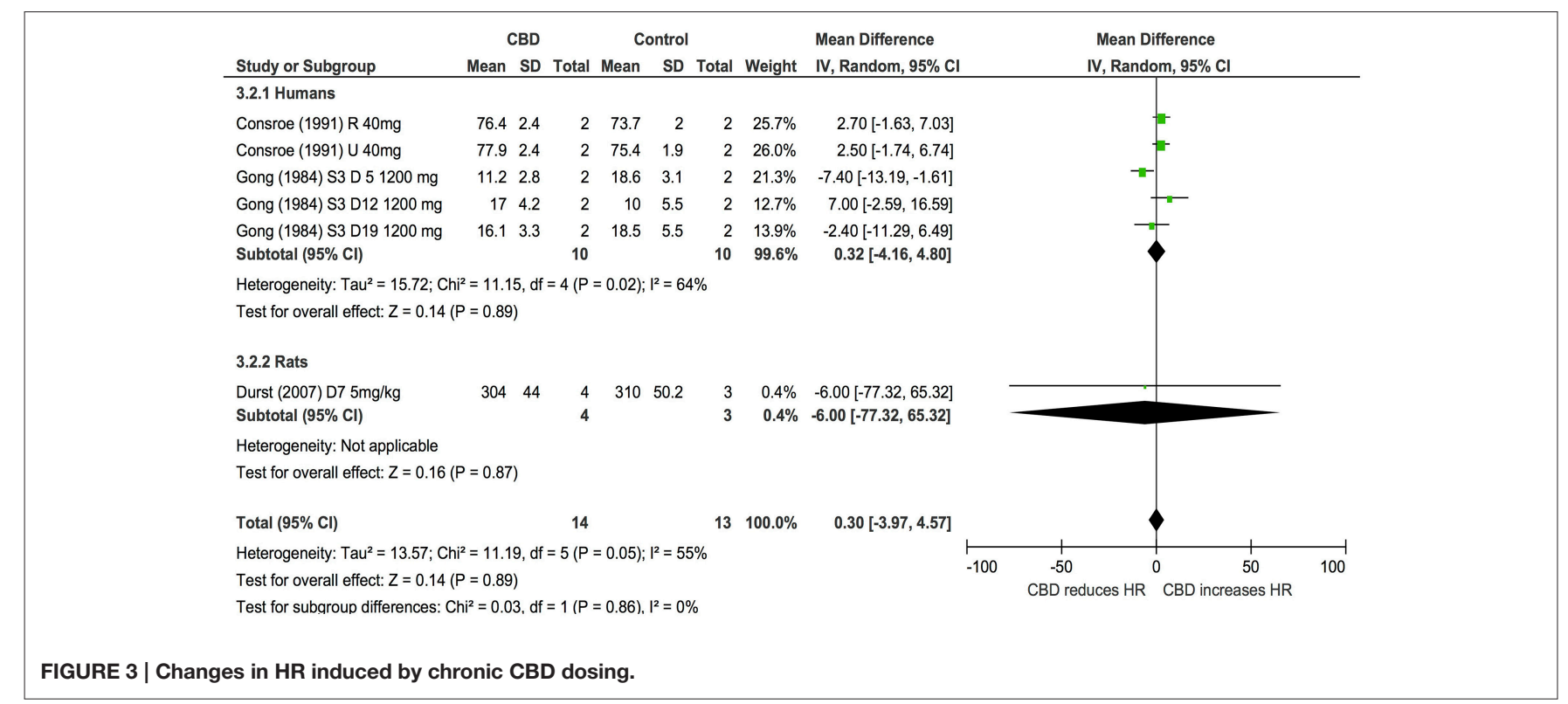

administration of CBD (HR control $p=0.01$; HR stress $p=0.049$; Figure 7).

\section{DISCUSSION}

The aim of this study was to determine whether CBD alters haemodynamics in vivo. Our analysis has shown that acute and chronic dosing of CBD had no effect on BP, HR, or BF under control conditions. However, in stressful situations, CBD reduces the increase in MBP and HR observed in rats. Subgroup analysis revealed that acute $\mathrm{CBD}$ administration increases HR in mice and rats, and increases CBF in mouse models of stroke. Our analysis has highlighted the limited amount of human research carried out to date, and suggests that further work is required to assess the haemodynamic and regional $\mathrm{BF}$ impact of acute and chronic CBD administration in healthy volunteers and patients.

Overall, our meta-analysis showed that acute and chronic dosing of CBD had no effect on BP, HR, or BF under control conditions. However, there was significant heterogeneity with regards to species and model, dose and route of administration, and method and time of endpoint measurement (see Table 1) which makes it difficult to compare studies. It is possible that species differences may play a role. For example, Bright et al. found a significant increase in HR and BP with CBD (0.5 and $1 \mathrm{mg} / \mathrm{kg}$ ) in anesthetized dogs (Bright et al., 1974, 1975), however, no changes were seen with CBD $(25 \mathrm{mg} / \mathrm{kg})$ in the HR of anesthetized rabbits (Borgen and Davis, 1974). It is also worth noting that most of the human data reviewed did not show any significant effects of CBD while significant effects were observed in animal studies. The time of cardiovascular measurements is also very important. For example, in a study that examined the cardioprotective effect of CBD $(50 \mu \mathrm{g} / \mathrm{kg}$ i.v.) in rats showed that $\mathrm{BP}$ was significantly reduced postCBD treatment compared to control two and a half hours post-ischaemia (Walsh et al., 2010). However, another study assessing $\mathrm{CBD}$ at the same dose and route of administration on cardiac arrhythmia (Gonca and Darici, 2015) found no change in BP, although this was only measured 11 min post-ischaemia, thus any potential later changes in haemodynamics are not reported. A greater number of homogenous studies are required to assess the haemodynamic effects of CBD under control conditions.

Our systematic review has highlighted that there are a limited number of studies examining changes in regional $\mathrm{BF}$ with $\mathrm{CBD}$, with studies to date only examining changes in cerebral or myocardial BF. From the limited studies available, our analysis showed there were no significant changes in $\mathrm{BF}$ overall post-CBD administration. However, in mice and piglet models of stroke, either intraperitoneal or intravenous administration of CBD $(3 \mathrm{mg} / \mathrm{kg}$ or $0.1 \mathrm{mg} / \mathrm{kg}$, respectively) significantly reduced the infarct volume and increased the CBF after acute and chronic dosing (Mishima et al., 2005; Hayakawa et al., 2007a,b; Alvarez et al., 2008). Similarly, in a rabbit model of myocardial infarction, CBD treatment of $100 \mu \mathrm{g} / \mathrm{kg}$ modestly reduced the size of myocardial ischaemic injury and increased myocardial BF (Feng et al., 2015). Together, this suggests that further investigation on the effects of $\mathrm{CBD}$ on regional $\mathrm{BF}$, particularly in pathological situations, is warranted.

There was no relationship found between the dose of CBD and the effect size. However, in conscious monkeys, toxicology studies showed that very large doses of CBD $(150-300 \mathrm{mg} / \mathrm{kg})$ caused bradycardia, and CBD doses $>200 \mathrm{mg} / \mathrm{kg}$ caused heart failure and death (Rosenkrantz et al., 1981). However, it is worth noting that this would be equivalent to a dose of $14,000 \mathrm{mg}$ in a $70 \mathrm{~kg}$ human. Intracisternal administration of $\mathrm{CBD}$ had no effect on the increase in BP or HR induced by acute restraint stress in rats while systemic administration did (Granjeiro et al., 2011). Similarly, no effect was seen in BP after intracerebral 


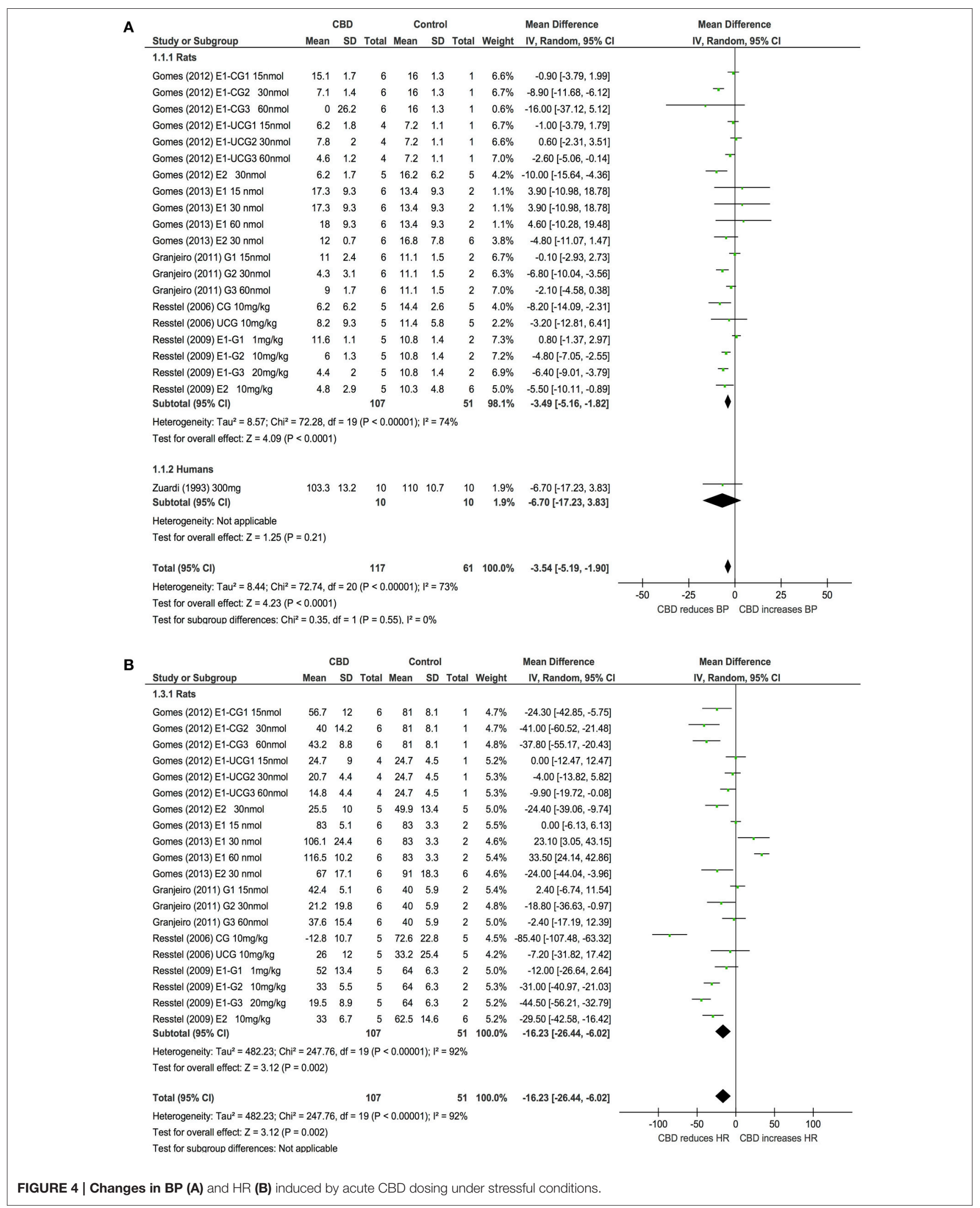



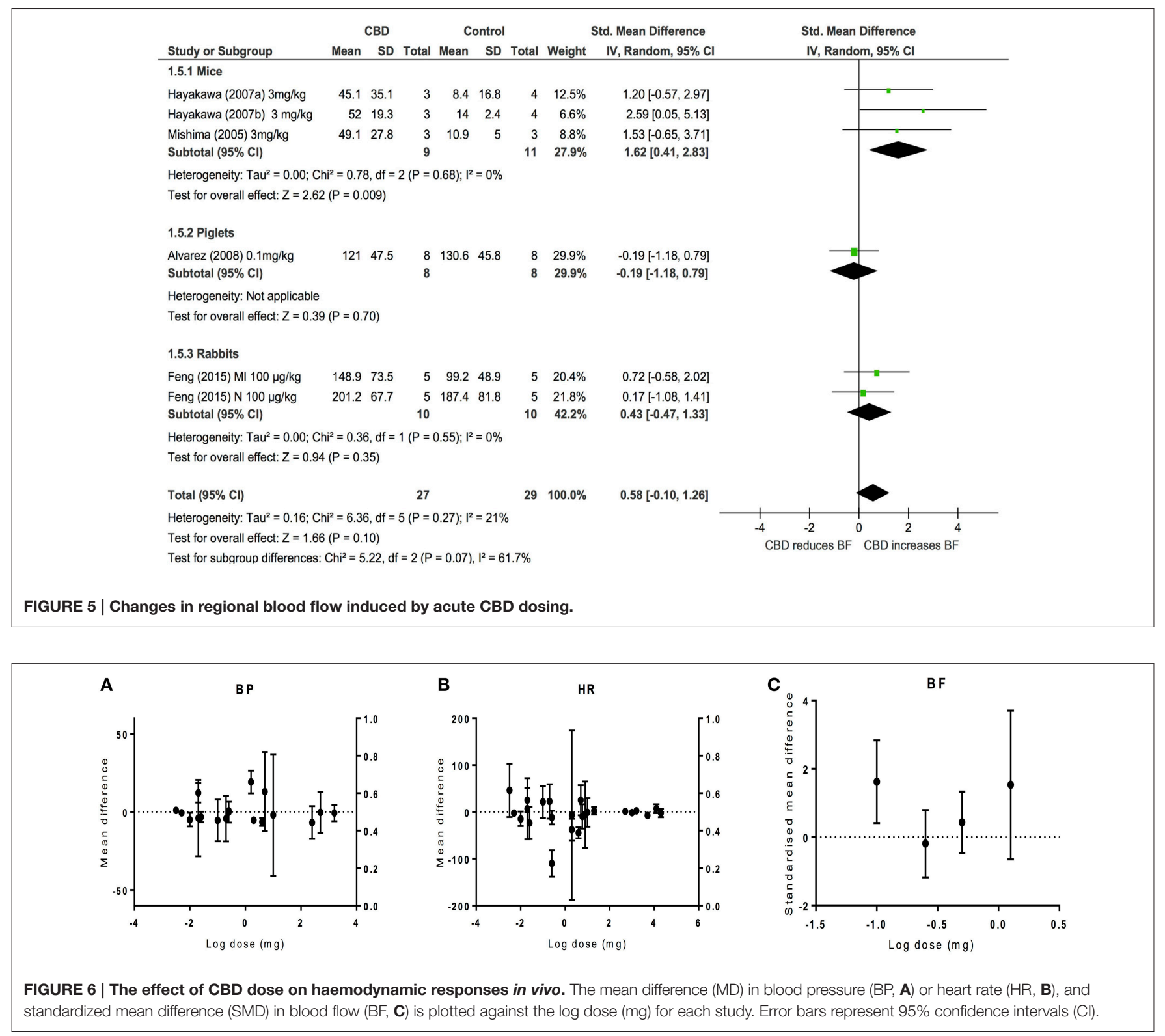

CBD injection in rats (Gomes et al., 2013). This suggests that systemic administration of $\mathrm{CBD}$ is required to observe changes in haemodynamics.

Although CBD did not affect haemodynamics under control conditions, our analysis did reveal effects of CBD in pathological situations. For example, in piglet models of hypoxic injury, intravenous administration of CBD $(0.1 \mathrm{mg} / \mathrm{kg})$ maintained a stable BP after hypoxic injury compared to control animals where a reduction in BP was observed (Alvarez et al., 2008). Also, in rats conditioned to stress (i.e., restraint or fear), $\mathrm{CBD}$ reduced the increase in $\mathrm{HR}$ and MBP (Resstel et al., 2006, 2009; Gomes et al., 2012). However, in mouse models of stroke there was no significant change in MBP or HR post-CBD (Mishima et al., 2005; Hayakawa et al., 2007a, 2008). This suggests that CBD may regulate the haemodynamics when they are altered at times of stress or acute illness.

Most of the identified relevant studies were pre-clinical, and data concerning the effects of CBD on haemodynamics in humans is limited ( $n=36$ for $\mathrm{BP}, n=87$ for $\mathrm{HR}$ ). A single oral dose of CBD $(320 \mu \mathrm{g} / \mathrm{kg}, 1 \mathrm{mg} / \mathrm{kg}, 100,300$, 600 or $1200 \mathrm{mg}$ ) had no effect on BP or HR in healthy volunteers under control or stressful situations (Belgrave et al., 1979; Zuardi et al., 1982, 1993; Gong et al., 1984; Borgwardt et al., 2008; Bhattacharyya et al., 2009, 2010; Fusar-Poli et al., 2009; Bergamaschi et al., 2011; Hallak et al., 2011; WintonBrown et al., 2011; Martin-Santos et al., 2012). Likewise, after repeated CBD dosing of $1200 \mathrm{mg}$ or $3 \mathrm{mg} / \mathrm{kg}$ for 20 or 30 days, respectively there were no apparent effects on $\mathrm{HR}$, $\mathrm{BP}$, or ECG compared with other treatment groups (Cunha 
A BP

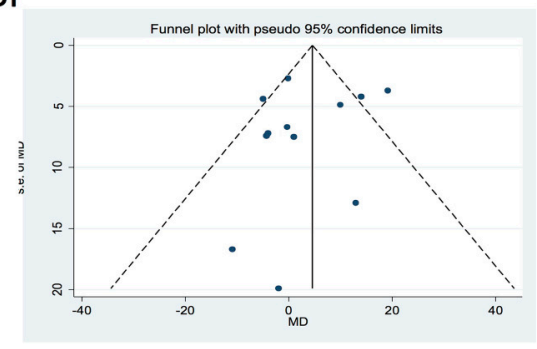

D BP (stress group)

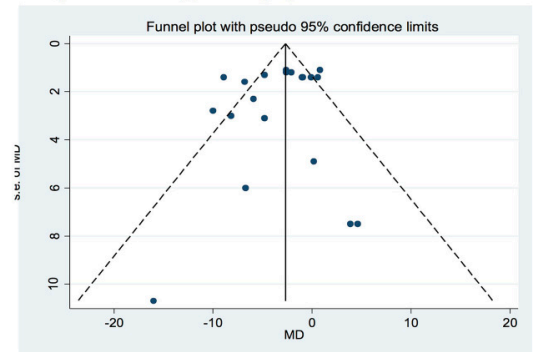

B HR

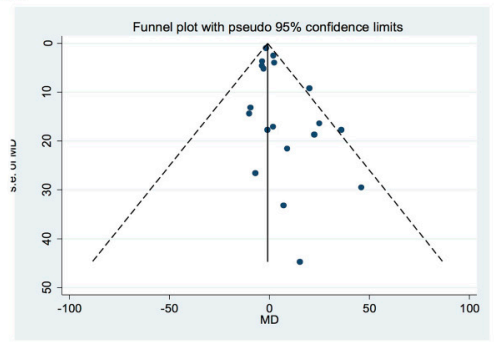

E HR (stress group)

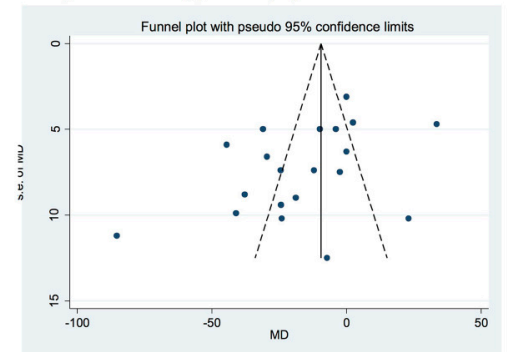

\section{c BF}

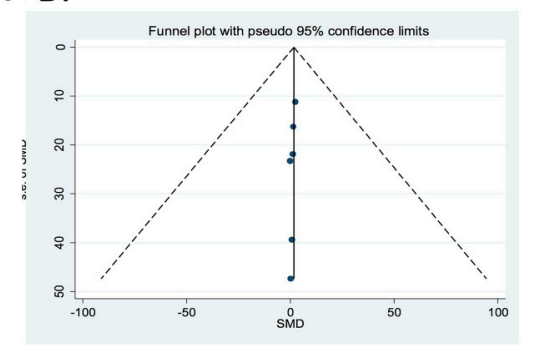

F HR (chronic)

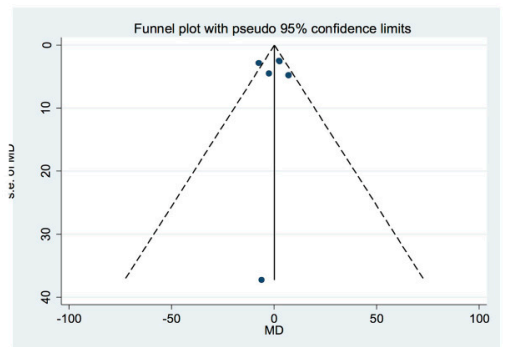

FIGURE 7 | Funnel plots for each outcome evaluating publication bias. Standard error (SE) of the mean difference (MD) in blood pressure (BP) and heart rate $(\mathrm{HR})$, or of the standardized mean difference in blood flow (BF, MD, or SMD, y axes) for each study is plotted against its effect size (horizontal axes). There was significant bias in HR after acute dosing (B, HR control $p=0.001$; E, HR stress $p=0.049$ ).

et al., 1980; Gong et al., 1984). In clinical trials, chronic administration of CBD $300 \mathrm{mg}, 10 \mathrm{mg} / \mathrm{kg}$ or $800 \mathrm{mg}$ for $4 \frac{1}{2}$ months, 6 or 4 weeks, respectively, incurred no changes on the ECG, BP, or HR in patients of epilepsy, Huntington or schizophrenia disorders (Cunha et al., 1980; Consroe et al., 1991; Leweke et al., 2012). However, repeated oral dosing of CBD increasing from 100 to $600 \mathrm{mg}$ /day over 6 weeks induced a reduction in standing $\mathrm{BP}$ by $10-20 \mathrm{mmHg}$ in patients with dystonic movement disorders (Consroe et al., 1986). Conversely, a single dose of CBD ( $40 \mathrm{mg}$ ) given to patients with intraocular pressure increased systolic BP at 60 and 90 min post-sublingual administration (Tomida et al., 2006). Two studies of healthy volunteers and patients with social anxiety disorders showed CBD (400 mg) increased cerebral BF on the left parahippocampal and right posterior cingulate gyrus, respectively, but not in other brain regions when compared to control (Crippa et al., 2004, 2011). Bhattacharyya et al. (2010) suggested that the $\mathrm{CBD}$ effects on regional brain function during multi-tasking may be related to its effects on CBF (Bhattacharyya et al., 2010). Conversely, Borgwardt et al. (2008) suggested that the neural effects observed after CBD administration are unlikely to be a consequence of vascular effects, including CBF (Borgwardt et al., 2008). Together, this data would suggest that there are limited haemodynamic effects of CBD in humans, although further studies where this is the primary endpoint are warranted based on pre-clinical data reviewed in the present study.

\section{Limitations}

There are several factors that limit the interpretation of the results of these studies and the understanding of the CBD effects on haemodynamics. In general, the primary aim of the studies reviewed was not to assess the haemodynamic effects of CBD. Some studies did not include an impartial measurement of BP or HR which may lead to bias in their outcome, or did not state the method of measurement. Due to the presence of heterogeneity in publications, outcomes after acute and chronic dosing should be interpreted with caution. After acute dosing, changes in haemodynamics at $2 \mathrm{~h}$ or the closest time point available to 2 $h$ post-drug were used for analysis, however, depending on the route of administration, the peak changes in plasma CBD and therefore associated cardiovascular changes, will be different. In chronic studies, the length of drug administration also varied. For the analysis of the relationship between drug dose and effect size, the total dose up to the time point in which the haemodynamic was measured was used in the analysis, this also may affect review conclusions. Only 9 out of 24 publications used randomisation and 6 reported blinding assessment of outcome, parameters that should impact on study quality. However, we found no relationship between quality and effect size. Finally, in some publications involving comparison of several doses, the number of animals per control group was divided into the number of comparison groups to avoid re-counting the same animal more than once, thus resulting in smaller sample sizes and broader estimates of the variance. 


\section{CONCLUSION}

This meta-analysis and systematic review has highlighted the haemodynamic effects of $\mathrm{CBD}$ administration in vivo. The positive effects induced by $\mathrm{CBD}$ include maintaining the fall in $\mathrm{BP}$ after global hypoxia, reducing the increase in MBP and HR post-stress, and increasing BF in ischaemia-reperfusion models. It is possible that beneficial effects of CBD on haemodynamics occurs when the cardiovascular system is abnormally altered, suggesting that $\mathrm{CBD}$ may be used as a treatment for various cardiovascular disorders, such as hypertension, myocardial infarction and stroke. However, the findings from the reviewed studies were predominately preclinical and significant effects were only observed in animals. Data from human studies

\section{REFERENCES}

Abati, E., Hess, E., Morgan, A., Bruno, P., and Thiele, E. (2015). "Cannabidiol treatment of refractory epileptic spasms: an open label study," in American Epilepsy Society Annual Meeting, Poster (Philadelphia).

Adams, R., Hunt, M., and Clark, J. H. (1940). Structure of cannabidiol, a product isolated from the marihuana extract of minnesota wild hemp. J. Am. Chem. Soc. 62, 196-200. doi: 10.1021/ja01858a058

Alvarez, F. J., Lafuente, H., Rey-Santano, M. C., Mielgo, V. E., Gastiasoro, E., Rueda, M., et al. (2008). Neuroprotective effects of the nonpsychoactive cannabinoid cannabidiol in hypoxic-ischemic newborn piglets. Pediatr. Res. 64, 653-658. doi: 10.1203/PDR.0b013e318186e5dd

Alves, F. H., Crestani, C. C., Gomes, F. V., Guimaraes, F. S., Correa, F. M. and Resstel, L. B. (2010). Cannabidiol injected into the bed nucleus of the stria terminalis modulates baroreflex activity through 5-HT1A receptors. Pharmacol Res. 62, 228-236. doi: 10.1016/j.phrs.2010.05.003

Belgrave, B. E., Bird, K. D., Chesher, G. B., Jackson, D. M., Lubbe, K. E., Starmer, G. A., et al. (1979). The effect of cannabidiol, alone and in combination with ethanol, on human performance. Psychopharmacology (Berl). 64, 243-246. doi: 10.1007/BF00496070

Bergamaschi, M. M., Queiroz, R. H., Chagas, M. H., de Oliveira, D. C., De Martinis, B. S., Kapczinski, F., et al. (2011). Cannabidiol reduces the anxiety induced by simulated public speaking in treatment-naive social phobia patients. Neuropsychopharmacology 36, 1219-1226. doi: 10.1038/npp.2011.6

Bhattacharyya, S., Fusar-Poli, P., Borgwardt, S., Martin-Santos, R., Nosarti, C., O'Carroll, C., et al. (2009). Modulation of mediotemporal and ventrostriatal function in humans by $\Delta 9$-tetrahydrocannabinol: a neural basis for the effects of Cannabis sativa on learning and psychosis. Arch. Gen. Psychiatry 66, 442-451. doi: 10.1001/archgenpsychiatry.2009.17

Bhattacharyya, S., Morrison, P. D., Fusar-Poli, P., Martin-Santos, R., Borgwardt, S., Winton-Brown, T., et al. (2010). Opposite effects of $\Delta$-9-tetrahydrocannabinol and cannabidiol on human brain function and psychopathology. Neuropsychopharmacology 35, 764-774. doi: 10.1038/npp.2009.184

Booz, G. W. (2011). Cannabidiol as an emergent therapeutic strategy for lessening the impact of inflammation on oxidative stress. Free Radic. Biol. Med. 51, 1054-1061. doi: 10.1016/j.freeradbiomed.2011.01.007

Borgen, L. A., and Davis, W. M. (1974). Cannabidiol interaction with delta9tetrahydrocannabinol. Res. Commun. Chem. Pathol. Pharmacol. 7, 663-670.

Borgwardt, S. J., Allen, P., Bhattacharyya, S., Fusar-Poli, P., Crippa, J. A., Seal, M. L., et al. (2008). Neural basis of $\Delta$-9-tetrahydrocannabinol and cannabidiol: effects during response inhibition. Biol. Psychiatry 64, 966-973. doi: 10.1016/j.biopsych.2008.05.011

Bright, T. P., Farber, M. O., Brown, D. J., and Forney, R. B. (1974). Cardiopulmonary effects of cannabidiol in anesthetized dogs. Pharmacologist 16:516.

Bright, T. P., Farber, M. O., Brown, D. J., Lewis, S. C., and Forney, R. B. (1975). Cardiopulmonary effects of cannabidiol in anesthetized mongrel dogs. Toxicol. Appl. Pharmacol. 31, 520-526. doi: 10.1016/0041-008X(75)90275-6 investigating the effects of CBD on haemodynamics is still very limited and we suggest that further research in humans under pathological conditions is required.

\section{AUTHOR CONTRIBUTIONS}

SO and TE: Substantial contributions to the conception or design of the work. All authors: The analysis and interpretation of data for the work; Drafting the work or revising it critically for important intellectual content; Final approval of the version to be published; Agreement to be accountable for all aspects of the work in ensuring that questions related to the accuracy or integrity of any part of the work are appropriately investigated and resolved.

Capasso, R., Borrelli, F., Aviello, G., Romano, B., Scalisi, C., Capasso, F., et al. (2008). Cannabidiol, extracted from Cannabis sativa, selectively inhibits inflammatory hypermotility in mice. Br. J. Pharmacol. 154, 1001-1008. doi: 10.1038/bjp.2008.177

Chagas, M. H., Zuardi, A. W., Tumas, V., Pena-Pereira, M. A., Sobreira, E. T., Bergamaschi, M. M., et al. (2014). Effects of cannabidiol in the treatment of patients with Parkinson's disease: an exploratory doubleblind trial. J. Psychopharmacol. 28, 1088-1098. doi: 10.1177/02698811145 50355

Consroe, P., Laguna, J., Allender, J., Snider, S., Stern, L., Sandyk, R., et al. (1991). Controlled clinical trial of cannabidiol in Huntington's disease. Pharmacol. Biochem. Behav. 40, 701-708. doi: 10.1016/0091-3057(91)90386-G

Consroe, P., Sandyk, R., and Snider, S. R. (1986). Open label evaluation of cannabidiol in dystonic movement disorders. Int. J. Neurosci. 30, 277-282. doi: 10.3109/00207458608985678

Crippa, J. A., Derenusson, G. N., Ferrari, T. B., Wichert-Ana, L., Duran, F. L., Martin-Santos, R., et al. (2011). Neural basis of anxiolytic effects of cannabidiol (CBD) in generalized social anxiety disorder: a preliminary report. J. Psychopharmacol. 25, 121-130. doi: 10.1177/0269881110379283

Crippa, J. A., Zuardi, A. W., Garrido, G. E., Wichert-Ana, L., Guarnieri, R., Ferrari, L., et al. (2004). Effects of cannabidiol (CBD) on regional cerebral blood flow. Neuropsychopharmacology 29, 417-426. doi: 10.1038/sj.npp.1300340

Cunha, J. M., Carlini, E. A., Pereira, A. E., Ramos, O. L., Pimentel, C., Gagliardi, R., et al. (1980). Chronic administration of cannabidiol to healthy volunteers and epileptic patients. Pharmacology 21, 175-185. doi: 10.1159/000137430

Devinsky, O., Marsh, E., Friedman, D., Thiele, E., Laux, L., Sullivan, J., et al. (2016). Cannabidiol in patients with treatment-resistant epilepsy: an open-label interventional trial. Lancet Neurol. 15, 270-278. doi: 10.1016/S1474-4422(15)00379-8

Durst, R., Danenberg, H., Gallily, R., Mechoulam, R., Meir, K., Grad, E., et al. (2007). Cannabidiol, a nonpsychoactive Cannabis constituent, protects against myocardial ischemic reperfusion injury. Am. J. Physiol. Heart Circ. Physiol. 293, H3602-H3607. doi: 10.1152/ajpheart.00098.2007

Egger, M., Davey Smith, G., Schneider, M., and Minder, C. (1997). Bias in meta-analysis detected by a simple, graphical test. BMJ 315, 629-634. doi: 10.1136/bmj.315.7109.629

England, T. J., Hind, W. H., Rasid, N. A., and O'Sullivan, S. E. (2015). Cannabinoids in experimental stroke: a systematic review and meta-analysis. J. Cereb. Blood Flow Metab. 35, 348-358. doi: 10.1038/jcbfm.2014.218

Feng, Y., Chen, F., Yin, T., Xia, Q., Liu, Y., Huang, G., et al. (2015). Pharmacologic effects of cannabidiol on acute reperfused myocardial infarction in rabbits: evaluated With 3.0T cardiac magnetic resonance imaging and histopathology. J. Cardiovasc. Pharmacol. 66, 354-363. doi: 10.1097/fjc.00000000000 00287

Fusar-Poli, P., Crippa, J. A., Bhattacharyya, S., Borgwardt, S. J., Allen, P., MartinSantos, R., et al. (2009). Distinct effects of $\Delta$-tetrahydrocannabinol and cannabidiol on neural activation during emotional processing. Arch. Gen. Psychiatry 66, 95-105. doi: 10.1001/archgenpsychiatry.2008.519 
Garberg, H. T., Huun, M. U., Escobar, J., Martinez-Orgado, J., Loberg, E. M., Solberg, R., et al. (2016). Short-term effects of cannabidiol after global hypoxiaischemia in newborn piglets. Pediatr Res. 80, 710-718. doi: 10.1038/pr.2016.149

Geffrey, G., Stephen, W., Alice, M., and Elizabeth, T. (2015). "Cannabidiol (CBD) treatment of refractory epilepsy in Tuberous Sclerosis Complex (TSC)," in American Epilepsy Society Annual Meeting, Poster (Philadelphia).

Gomes, F. V., Alves, F. H., Guimaraes, F. S., Correa, F. M., Resstel, L. B., and Crestani, C. C. (2013). Cannabidiol administration into the bed nucleus of the stria terminalis alters cardiovascular responses induced by acute restraint stress through 5- $\mathrm{HT}_{1}$ A receptor. Eur. Neuropsychopharmacol. 23, 1096-1104. doi: 10.1016/j.euroneuro.2012.09.007

Gomes, F. V., Reis, D. G., Alves, F. H., Corrêa, F. M., Guimarães, F. S., and Resstel, L. B. (2012). Cannabidiol injected into the bed nucleus of the stria terminalis reduces the expression of contextual fear conditioning via $5-\mathrm{HT}_{1} \mathrm{~A}$ receptors. J. Psychopharmacol. 26, 104-113. doi: 10.1177/0269881110389095

Gonca, E., and Darici, F. (2015). The effect of cannabidiol on ischemia/reperfusioninduced ventricular arrhythmias: the role of adenosine $A_{1}$ receptors. J. Cardiovasc. Pharmacol. Ther. 20, 76-83. doi: 10.1177/1074248414532013

Gong, H. Jr., Tashkin, D. P., Simmons, M. S., Calvarese, B., and Shapiro, B. J. (1984). Acute and subacute bronchial effects of oral cannabinoids. Clin. Pharmacol. Ther. 35, 26-32. doi: 10.1038/clpt.1984.4

Granjeiro, E. M., Gomes, F. V., Guimarães, F. S., Corrêa, F. M., and Resstel, L. B. (2011). Effects of intracisternal administration of cannabidiol on the cardiovascular and behavioral responses to acute restraint stress. Pharmacol. Biochem. Behav. 99, 743-748. doi: 10.1016/j.pbb.2011.06.027

Hallak, J. E., Dursun, S. M., Bosi, D. C., de Macedo, L. R., Machado-deSousa, J. P., Abrão, J., et al. (2011). The interplay of cannabinoid and NMDA glutamate receptor systems in humans: preliminary evidence of interactive effects of cannabidiol and ketamine in healthy human subjects. Prog. Neuropsychopharmacol. Biol. Psychiatry 35, 198-202. doi: 10.1016/j.pnpbp.2010.11.002

Hayakawa, K., Mishima, K., Irie, K., Hazekawa, M., Mishima, S., Fujioka, M., et al. (2008). Cannabidiol prevents a post-ischemic injury progressively induced by cerebral ischemia via a high-mobility group box1-inhibiting mechanism. Neuropharmacology 55, 1280-1286. doi: 10.1016/j.neuropharm.2008.06.040

Hayakawa, K., Mishima, K., Nozako, M., Hazekawa, M., Irie, K., Fujioka, M., et al. (2007a). Delayed treatment with cannabidiol has a cerebroprotective action via a cannabinoid receptor-independent myeloperoxidase-inhibiting mechanism. J. Neurochem. 102, 1488-1496. doi: 10.1111/j.1471-4159.2007.04565.x

Hayakawa, K., Mishima, K., Nozako, M., Ogata, A., Hazekawa, M., Liu, A. X., et al. (2007b). Repeated treatment with cannabidiol but not Delta9-tetrahydrocannabinol has a neuroprotective effect without the development of tolerance. Neuropharmacology 52, 1079-1087. doi: 10.1016/j.neuropharm.2006.11.005

Higgins, J. P., Altman, D. G., Gotzsche, P. C., Jüni, P., Moher, D., Oxman, A. D., et al. (2011). The cochrane Collaboration's tool for assessing risk of bias in randomised trials. BMJ 343:d5928. doi: 10.1136/bmj.d5928

Hind, W. H., England, T. J., and O'Sullivan, S. E. (2016). Cannabidiol protects an in vitro model of the blood-brain barrier from oxygen-glucose deprivation via PPARgamma and 5- $\mathrm{HT}_{1} \mathrm{~A}$ receptors. Br. J. Pharmacol. 173, 815-825. doi: 10.1111/bph.13368

Iuvone, T., Esposito, G., De Filippis, D., Scuderi, C., and Steardo, L. (2009). Cannabidiol: a promising drug for neurodegenerative disorders? CNS Neurosci. Ther. 15, 65-75. doi: 10.1111/j.1755-5949.2008.00065.x

Leweke, F. M., Piomelli, D., Pahlisch, F., Muhl, D., Gerth, C. W., Hoyer, C., et al. (2012). Cannabidiol enhances anandamide signaling and alleviates psychotic symptoms of schizophrenia. Transl. Psychiatry 2:e94. doi: 10.1038/tp.2012.15

Martin-Santos, R., Crippa, J. A., Batalla, A., Bhattacharyya, S., Atakan, Z., Borgwardt, S., et al. (2012). Acute effects of a single, oral dose of d9-tetrahydrocannabinol (THC) and cannabidiol (CBD) administration in healthy volunteers. Curr. Pharm. Des. 18, 4966-4979. doi: 10.2174/138161212802884780

Mishima, K., Hayakawa, K., Abe, K., Ikeda, T., Egashira, N., Iwasaki, K., et al. (2005). Cannabidiol prevents cerebral infarction via a serotonergic 5hydroxytryptamine ${ }_{1 \mathrm{~A}}$ receptor-dependent mechanism. Stroke 36, 1077-1082. doi: 10.1161/01.STR.0000163083.59201.34

Nadulski, T., Pragst, F., Weinberg, G., Roser, P., Schnelle, M., Fronk, E. M., et al. (2005a). Randomized, double-blind, placebo-controlled study about the effects of cannabidiol (CBD) on the pharmacokinetics of Delta9-tetrahydrocannabinol (THC) after oral application of THC verses standardized cannabis extract. Ther. Drug Monit. 27, 799-810. doi: 10.1097/01.ftd.0000177223.19294.5c

Nadulski, T., Sporkert, F., Schnelle, M., Stadelmann, A. M., Roser, P., Schefter, T., et al. (2005b). Simultaneous and sensitive analysis of THC, 11-OH-THC, THC-COOH, CBD, and CBN by GC-MS in plasma after oral application of small doses of THC and cannabis extract. J. Anal. Toxicol. 29, 782-789. doi: $10.1093 /$ jat/29.8.782

O’Sullivan, S. E., Sun, Y., Bennett, A. J., Randall, M. D., and Kendall, D. A. (2009). Time-dependent vascular actions of cannabidiol in the rat aorta. Eur. J. Pharmacol. 612, 61-68. doi: 10.1016/j.ejphar.2009.03.010

Pazos, M. R., Mohammed, N., Lafuente, H., Santos, M., Martinez-Pinilla, E., Moreno, E., et al. (2013). Mechanisms of cannabidiol neuroprotection in hypoxic-ischemic newborn pigs: role of $5 \mathrm{HT}(1 \mathrm{~A})$ and $\mathrm{CB} 2$ receptors. Neuropharmacology 71, 282-291. doi: 10.1016/j.neuropharm.2013.03.027

Pertwee, R. G. (2006). Cannabinoid pharmacology: the first 66 years. Br. J. Pharmacol. 147(Suppl. 1), S163-S171. doi: 10.1038/sj.bjp.0706406

Pertwee, R. G. (2008). The diverse CB1 and CB2 receptor pharmacology of three plant cannabinoids: delta9-tetrahydrocannabinol, cannabidiol and delta9-tetrahydrocannabivarin. Br. J. Pharmacol. 153, 199-215. doi: 10.1038/sj.bjp.0707442

Rajesh, M., Mukhopadhyay, P., Bátkai, S., Haskó, G., Liaudet, L., Drel, V. R., et al. (2007). Cannabidiol attenuates high glucose-induced endothelial cell inflammatory response and barrier disruption. Am. J. Physiol. Heart Circ. Physiol. 293, H610-H619. doi: 10.1152/ajpheart.00236.2007

Rajesh, M., Mukhopadhyay, P., Batkai, S., Patel, V., Saito, K., Matsumoto, S., et al. (2010). Cannabidiol attenuates cardiac dysfunction, oxidative stress, fibrosis, and inflammatory and cell death signaling pathways in diabetic cardiomyopathy. J. Am. Coll. Cardiol. 56, 2115-2125. doi: 10.1016/j.jacc.2010.07.033

Resstel, L. B., Joca, S. R., Moreira, F. A., Corrêa, F. M., and Guimarães, F. S. (2006). Effects of cannabidiol and diazepam on behavioral and cardiovascular responses induced by contextual conditioned fear in rats. Behav. Brain Res. 172, 294-298. doi: 10.1016/j.bbr.2006.05.016

Resstel, L. B., Tavares, R. F., Lisboa, S. F., Joca, S. R., Correa, F. M., and Guimaraes, F. S. (2009). 5- $\mathrm{HT}_{1} \mathrm{~A}$ receptors are involved in the cannabidiol-induced attenuation of behavioural and cardiovascular responses to acute restraint stress in rats. Br. J. Pharmacol. 156, 181-188. doi: 10.1111/j.1476-5381.2008.00046.x

Rosenkrantz, H., Fleischman, R. W., and Grant, R. J. (1981). Toxicity of short-term administration of cannabinoids to rhesus monkeys. Toxicol. Appl. Pharmacol. 58, 118-131. doi: 10.1016/0041-008X(81)90122-8

Ruiz-Valdepenas, L., Martinez-Orgado, J. A., Benito, C., Millan, A., Tolon, R. M., and Romero, J. (2011). Cannabidiol reduces lipopolysaccharideinduced vascular changes and inflammation in the mouse brain: an intravital microscopy study. J. Neuroinflammation 8:5. doi: 10.1186/1742-2094-8-5

Russo, E., and Guy, G. W. (2006). A tale of two cannabinoids: the therapeutic rationale for combining tetrahydrocannabinol and cannabidiol. Med. Hypotheses 66, 234-246. doi: 10.1016/j.mehy.2005.08.026

Stanley, C. P., Hind, W. H., and O'Sullivan, S. E. (2013a). Is the cardiovascular system a therapeutic target for cannabidiol? Br. J. Clin. Pharmacol. 75, 313-322. doi: 10.1111/j.1365-2125.2012.04351.x

Stanley, C. P., Hind, W. H., Tufarelli, C., and O'Sullivan, S. E. (2015). Cannabidiol causes endothelium-dependent vasorelaxation of human mesenteric arteries via CB1 activation. Cardiovasc. Res. 107, 568-578. doi: 10.1093/cvr/cvv179

Stanley, C. P., Wheal, A. J., Randall, M. D., and O'Sullivan, S. E. (2013b). Cannabinoids alter endothelial function in the Zucker rat model of type 2 diabetes. Eur. J. Pharmacol. 720, 376-382. doi: 10.1016/j.ejphar.2013. 10.002

Stroke Therapy Academic Industry Roundtable (1999). Recommendations for standards regarding preclinical neuroprotective and restorative drug development. Stroke 30, 2752-2758. doi: 10.1161/01.STR.30.12.2752

Tambaro, S., and Bortolato, M. (2012). Cannabinoid-related agents in the treatment of anxiety disorders: current knowledge and future perspectives. Recent Pat. CNS Drug Discov. 7, 25-40. doi: 10.2174/157488912798842269

Thomas, A., Baillie, G. L., Phillips, A. M., Razdan, R. K., Ross, R. A., and Pertwee, R. G. (2007). Cannabidiol displays unexpectedly high potency as an antagonist of CB1 and CB2 receptor agonists in vitro. Br. J. Pharmacol. 150, 613-623. doi: $10.1038 /$ sj.bjp. 0707133 
Tomida, I., Azuara-Blanco, A., House, H., Flint, M., Pertwee, R. G., and Robson, P. J. (2006). Effect of sublingual application of cannabinoids on intraocular pressure: a pilot study. J. Glaucoma 15, 349-353. doi: 10.1097/01.ijg.0000212260.04488.60

Walsh, S. K., Hepburn, C. Y., Kane, K. A., and Wainwright, C. L. (2010). Acute administration of cannabidiol in vivo suppresses ischaemia-induced cardiac arrhythmias and reduces infarct size when given at reperfusion. $\mathrm{Br}$. J. Pharmacol. 160, 1234-1242. doi: 10.1111/j.1476-5381.2010.00755.x

Wheal, A. J., Cipriano, M., Fowler, C. J., Randall, M. D., and O'Sullivan, S. E. (2014). Cannabidiol improves vasorelaxation in Zucker diabetic fatty rats through cyclooxygenase activation. J. Pharmacol. Exp. Ther. 351, 457-466. doi: 10.1124/jpet.114.217125

Winton-Brown, T. T., Allen, P., Bhattacharyya, S., Borgwardt, S. J., FusarPoli, P., Crippa, J. A., et al. (2011). Modulation of auditory and visual processing by delta-9-tetrahydrocannabinol and cannabidiol: an FMRI study. Neuropsychopharmacology 36, 1340-1348. doi: 10.1038/npp.2011.17

Zuardi, A. W. (2008). Cannabidiol: from an inactive cannabinoid to a drug with wide spectrum of action. Rev. Bras. Psiquiatr. 30, 271-280. doi: 10.1590/S1516-44462008000300015
Zuardi, A. W., Cosme, R. A., Graeff, F. G., and Guimaraes, F. S. (1993). Effects of ipsapirone and cannabidiol on human experimental anxiety. J. Psychopharmacol. 7, 82-88.

Zuardi, A. W., Shirakawa, I., Finkelfarb, E., and Karniol, I. G. (1982) Action of cannabidiol on the anxiety and other effects produced by delta 9-THC in normal subjects. Psychopharmacology (Berl). 76, 245-250. doi: $10.1007 / B F 00432554$

Conflict of Interest Statement: The authors declare that the research was conducted in the absence of any commercial or financial relationships that could be construed as a potential conflict of interest.

Copyright (c) 2017 Sultan, Millar, England and O'Sullivan. This is an open-access article distributed under the terms of the Creative Commons Attribution License (CC BY). The use, distribution or reproduction in other forums is permitted, provided the original author(s) or licensor are credited and that the original publication in this journal is cited, in accordance with accepted academic practice. No use, distribution or reproduction is permitted which does not comply with these terms. 